Maurice A. Deane School of Law at Hofstra University Scholarly Commons at Hofstra Law

Hofstra Law Faculty Scholarship

1971

\title{
Sex Discrimination and Equal Protection: Do We Need a Constitutional Amendment?
}

Andrew Schepard

Maurice A. Deane School of Law at Hofstra University

Follow this and additional works at: https://scholarlycommons.law.hofstra.edu/faculty_scholarship

\section{Recommended Citation}

Andrew Schepard, Sex Discrimination and Equal Protection: Do We Need a Constitutional Amendment?, 84 Harv. L. Rev. 1499 (1971) Available at: https://scholarlycommons.law.hofstra.edu/faculty_scholarship/748

This Article is brought to you for free and open access by Scholarly Commons at Hofstra Law. It has been accepted for inclusion in Hofstra Law Faculty Scholarship by an authorized administrator of Scholarly Commons at Hofstra Law. For more information, please contact lawcls@hofstra.edu. 


\title{
SEX DISCRIMINATION AND EQUAL PROTECTION: DO WE NEED A CONSTITUTIONAL AMENDMENT?
}

\begin{abstract}
A woman cannot be herself in modern society. It is an exchsively male society, with laws made by men and with prosecutors and judges who assess female conduct from a male standpoint.

- Henrik Ibsen ${ }^{1}$

Equality of rights under the law shall not be denied or abridged by the United States or by any State on account of sex.

- Proposed Amendment to the Constitution of the United States ${ }^{2}$
\end{abstract}

Since Ibsen wrote at the turn of the century, traditional conceptions of women's role in society have been seriously shaken. The increased sensitivity of many women to sexual discrimination ${ }^{3}$ and the debunking of myths concerning feminine physical capabilities and moral sensitivities have eliminated many exclusive male bastions in both social and professional life. ${ }^{4}$ Not surprisingly, laws which use sex as a distinguishing characteristic have also come under attack. Activity on the legal front reached a peak in the 9ist Congress when the House of Representatives passed, and over forty Senators cosponsored, a proposed equal rights amendment designed to end legal sex discrimination. After extensive hearings before the Senate Judiciary Committee, ${ }^{5}$ however, the amendment was defeated on the Senate floor. ${ }^{\circ}$

The amendment's defeat was apparently the result of serious objections raised in the committee hearings. Although almost everyone who testified acknowledged that some statutory restraints on women are both archaic and unnecessary, ${ }^{7}$ there was much disagreement as to whether a constitutional amendment is the proper vehicle for reform. Opposition seemed to stem from the belief that sexual distinctions make up such a significant part

${ }^{1}$ Quoted in Meyer, Introduction to H. IBSEN, A DorL's House at 9 (M. Meyer transl. 1965 ).

${ }^{2}$ S.J. Res. 6I, gIst Cong., Ist Sess. \$ I (r969).

${ }^{3}$ See, e.g., Gornick, Consciousness 9 , N.Y. Times, Jan. Io, I971, § 6 (Magazine), at 22. See generally K. MInLetr, Sexuad Politics (1970).

4See, e.g., N.Y. Times, Feb. 4, I97I, at $x$, col. 2 (New York City school system considering allowing both sexes to compete in some high school sports presently limited to males).

"Hearings on S.J. Res. 6r \& S.J. Res. 231 Before the Senate Comm. on the Judiciary, 9rst Cong., 2d Sess. (1970) [hereinafter cited as Hearings].

${ }^{B}$ Committee on Federal Legislation, Association of the Bar of the City of New York, Amending the Constitution to Prohibit State Discrimination Based on Sex, 26 RECORD of N.Y.C.B.A. 77 (I97I) [hereinafter cited as Report].

${ }^{7}$ See, e.g., id. at 74 (testimony of Harvard Law School Professor Paul Freund) (many laws are "oppressive discriminations on account of sex"). 
of the country's legal mosaic ${ }^{8}$ that the blunderbuss of a constitutional amendment would shatter a delicate pattern, some parts of which may be worthy of preservation. ${ }^{9}$

Most people would probably agree that many sex-distinguishing statutes should be eliminated. There are, for example, some statutes whose only apparent purpose is to raise ancient chivalric notions to the level of state protection; in some jurisdictions it is a criminal offense for a male to use obscene language in the presence of a female, but not an offense for a female to do so in the presence of a male. ${ }^{10}$ Other statutes may simply codify a double standard as to the relative freedom of males and females to depart from conventional morals; in some jurisdictions, for example, a statutory defense is available to the husband who murders his wife's paramour but not to the wife who kills her husband's mistress. ${ }^{11}$ Still other sex distinctions are vestiges of the old common law doctrine of coverture, which treated husband and wife as a single legal entity; thus, a married woman's domicile, with all its legal ramifications, ${ }^{12}$ is generally determined by her husband's, even though they may live miles apart. ${ }^{13}$

Nevertheless, many people would disagree as to the merit of eliminating statutes which "protect" women ${ }^{14}$ or are based on some alleged difference in physiology or ability. Some sex dis-

\footnotetext{
${ }^{8}$ Several compendiums of sex distinctions and discriminations in American law are available. Note, Sex, Discrimination, and the Constitution, 2 Stan. L. Rev. 69I (1950), provides an overview of the situation existing in 1950 . Recent developments and incisive analysis are contained in a two-part series by Leo Kanowitz, Sex-Based Discrimination in American Law I: Law and the Single Girl, I I St. Lours U.L.J. 293 (1967) [hereinafter cited as Kanowitz, Single Girl] and SexBased Discrimination in American Law II: Law and the Married Woman, I2 St. Lours U.L.J. 3 (1967) [hereinafter cited as Kanowitz, Married Woman]. See Report 84-90 for a comprehensive collection of the most significant cases evaluating the constitutionality of sex distinctions.

${ }^{9}$ See, e.g., Hearings 74 (testimony of Professor Freund).

${ }^{10}$ Kanowitz, Constitutional Aspects of Sex-Based Discrimination in American Law, 48 NeB. L. REv. I3I, 160-64 (I968) [hereinafter cited as Kanowitz, Constitutional Aspects]. For another example of an attempt to protect the sensibilities of women, see Abbott v. Mines, 4II F.2d 353 (6th Cir. 1969), in which a trial judge was held to have abused his discretion by excluding all women from a jury panel merely because the issue in the case involved a discussion of cancer of the penis.

${ }^{11}$ Kanowitz, Married Woman 6x-62.

${ }^{12}$ Domicile, for example, is important in determining eligibility for state benefits (such as free tuition at public colleges) and for court jurisdiction. Id. at $\mathbf{I} 6$.

${ }^{13} \mathrm{Id}$. at I6-I7. Many states, however, create an exception to the general rule when husband and wife live apart for cause. Id. at I7-r8.

${ }^{14}$ Some women's rights leaders argue, however, that such protective legislation really restricts opportunities for women. See, e.g., Seidenberg, The Submissive Majority: Modern Trends in the Law Concerning Women's Rights, 55 CORNELL L. REv. 262, 265-66 (1970).
} 
tinctions are designed to "protect" women from certain burdens of citizenship and social life. Some jurisdictions, for example, make jury duty a mandatory obligation for men but make service for women conditional on their affirmative request to serve. ${ }^{15}$ Many states have maximum hour and minimum wage laws applicable to women only. ${ }^{16}$ Some states deny women the freedom to engage in certain occupations, ranging from professional wrestler ${ }^{17}$ to liquor store salesman. ${ }^{18}$ Other laws distinguishing the sexes seem to reflect a legislative judgment about the relative capacities of men and women to care for children. Illinois, for example, requires a legal guardian for an illegitimate child when only his natural father is alive, but not if the surviving parent is his mother. ${ }^{19}$ Similarly, an Idaho statute, which gives an absolute preference to males over females in estate administration contests when two contenders for the job are otherwise equally qualified, ${ }^{20}$ may reflect a legislative judgment that males are more competent in managing financial and business affairs. Examples of laws which distinguish the sexes could be multiplied endlessly.

The procedure chosen for reworking this legal mosaic will have much to do with the scope of substantive reform achieved. Three possibilities have emerged from the congressional forum, where most current public discussion has been focused. First, Congress could take no further action, leaving the problem of evaluating sex distinctions to current statutory remedies ${ }^{21}$ and future constitutional doctrines developed by the judiciary. Second, Congress could pass additional legislation, within the limits of its constitutional powers, to eliminate specific instances of sex discrimination in federal, state, and private action. Finally, Congress could embody a proscription of sex discrimination in a constitutional amendment which would serve as a basis for judicial

${ }^{15}$ See Hoyt v. Florida, 368 U.S. 57 (196I). Only twenty-eight states permit women to serve on juries on the same basis as men. Hearings 306 (testimony of Yale Law School Professor Thomas Emerson).

${ }^{16}{ }_{113}$ CoNG. REC. 13,108 (I967) (remarks of Congresswoman Griffiths).

${ }^{17}$ See State v. Hunter, 208 Ore. 282, 300 P.2d 455 (1956).

${ }^{18}$ Hearings 306 (testimony of Professor Emerson).

${ }^{19}$ See In re Stanley, 45 Ill. $2 \mathrm{~d} 132,256$ N.E.2d 814 (1970), cert. granted sub nom. Stanley v. Illinois, $9 \mathrm{I} \mathrm{S.} \mathrm{Ct.} 584$ (I971).

${ }^{20}$ See Reed v. Reed, 93 Idaho 5II, 465 P.2d 635 (1970), cert. granted, 39 U.S.L.W. 3375 (U.S. Mar. I, I97I) (No. 430).

${ }^{21}$ See $\S 703(a)$ of Title VII of the Civil Rights Act of 1964,42 U.S.C. $\S$ 2000e-2(a) (Ig64). This Note will focus on constitutional aspects of sex discrimination and will not undertake any discussion of presently existing statutory remedies. For such a discussion, see Developments in the Law-Employment Discrimination and Title VII of the Civil Rights Act of 1964, 84 HaRv. L. REv. Irog, Ir66-95 (I97I). 
decision and might also augment congressional power to pass remedial legislation in the field. While the differences between proponents and opponents of a constitutional amendment have been cast primarily in terms of these procedural alternatives for change, each alternative carries with it a certain substantive bias. Assuming the need for some reform, analysis can expose the strengths and weaknesses of each approach and indicate the substantive results each is likely to bring about.

\section{The No Further Action Alternative - Leaving the Problem to the Courts.}

\section{A. Historical Background-Permissive Review}

Man is, or should be, woman's protector and defender. The natural and proper timidity and delicacy which belongs to the female sex evidently unfits it for many of the occupations of civil life. The constitution of the family organization, which is founded in the divine ordinance, as well as in the nature of things, indicates the domestic sphere as that which properly belongs to the domain and functions of womanhood.

- Bradwell v. Illinois ${ }^{22}$

While no Justice today would author an opinion containing such undisguised male bias, ${ }^{23}$ the Supreme Court has not yet held that a sex distinction has violated the equal protection clause of the fourteenth amendment. ${ }^{24}$ Recent decisions of the Court have upheld against equal protection challenge statutes which prohibit most women from engaging in the occupation of bartender ${ }^{25}$ and statutes which exempt them from jury duty unless they specifically request to serve. ${ }^{26}$ The Court's failure to eliminate legal sex discrimination has been the major motivating force behind the concerted campaign to secure congressional approval of a constitutional amendment. ${ }^{2 \pi}$

${ }^{22} 83$ U.S. (I6 Wall.) I30, I4I (I872) (Bradley, J., concurring).

${ }^{23} \mathrm{Cf}$. Paterson Tavern \& Grill Owners Ass'n v. Borough of Hawthorne, 57 N.J. 180, —, 270 A.2d 628, 630 (1970) (such judicial expressions "arose in a different social and moral climate when judges, along with others, entertained Victorian ideas as to women and their proper place in the scheme of things").

${ }^{24}$ See Report 79; Kanowitz, Constitutional Aspects 13I-33. Despite the absence of an equal protection clause in the fifth amendment, that amendment's due process clause incorporates equal protection concepts, restricting the power of the Federal Government as well as that of the states. Bolling v. Sharpe, 347 U.S. 497 (1954).

${ }^{25}$ Goesaert v. Cleary, 335 U.S. 464 (I948). But cf. Paterson Tavern \& Grill Owners Ass'n v. Borough of Hawthorne, 57 N.J. I80, 270 A.2d 628 (r97o) (similar borough regulation held to be unreasonable exercise of the police power).

${ }^{26}$ Hoyt v. Florida, 368 U.S. 57 (I96r).

${ }^{27}$ As one of the chief congressional sponsors of the equal rights amendment 
The cases and commentary surrounding the equal protection clause ${ }^{28}$ have articulated two primary standards of review to determine the validity of singling out one group of people for special legal treatment. The first standard, permissive review, generally defers to legislative judgment and upholds a distinction so long as the distinction can be reasonably construed as consistent with any legitimate governmental goal. ${ }^{29}$ Permissive review thus places a great burden on a party challenging the constitutionality of a distinction. The second standard, active review, scrutinizes the distinction more closely and places a heavy burden on the state to show that the distinction is related to some overriding state purpose. ${ }^{30}$ Active review is triggered either by statutes which affect certain "fundamental interests" (such as voting ${ }^{31}$ and procreation ${ }^{32}$ ) or by statutes which use "suspect classifications" (such as race ${ }^{33}$ or national ancestry ${ }^{34}$ ) to distinguish among individuals.

The Supreme Court has not yet found statutory classification by sex to be a suspect classification. Accordingly, unless a statute affects a fundamental interest, the Court utilizes the permissive standard to review sex distinctions. Using this standard in the bartender case, Goesaert v. Cleary, ${ }^{35}$ the Court ignored the obvious effect of the statute, monopolization of the profession for men. It sustained the law as having a rational relation to the legitimate, but far more subtle aim of avoiding the "moral and social problems" surrounding the employment of women in bars. $^{36}$ Yet it felt no need to articulate the nature of those problems nor the magnitude of the harms ensuing from them. It was sufficient that the legislature might have addressed itself to these difficulties and might have found them sufficiently compelling to require the statute. If statutes affecting an interest as important as the capacity of an individual to choose his calling stated: "This fight is with the Supreme Court." Hearings 228 (testimony of Congresswoman Griffiths).

${ }^{28}$ See generally Developments in the Law-Equal Protection, 82 HaRv. L. REv. I065 (1969) [hereinafter cited as Developments].

${ }^{29}$ See, e.g., Kotch v. Board of River Port Pilots Comm'rs, 330 U.S. 552 (1947). See generally Developments ro77-87.

${ }^{30}$ See, e.g., McLaughlin v. Florida, 379 U.S. $x 84$ (I964). See generally Developments $\mathrm{ros} 7-\mathrm{r}_{3} \mathrm{I}$.

${ }^{31}$ See, e.g., Harper v. Virginia Bd. of Elections, 383 U.S. $66_{3}$ (Ig66).

${ }^{32}$ See Skinner v. Oklahoma ex rel. Williamson, 3 I6 U.S. 535, 54I (r942).

${ }^{33} \mathrm{See}$, e.g., McLaughlin v. Florida, 379 U.S. I84 (1964).

${ }^{34}$ See Korematsu v. United States, 323 U.S. $21_{4}$ (1944).

${ }^{35} 335$ U.S. 464 (1948).

${ }^{30}$ Developments ro79; cf. State v. Hunter, 208 Ore. 282,300 P.2d 455 (1956), in which the court did attribute to a statute forbidding the licensing of women to be professional wrestlers the purpose of monopolizing the calling for men and still found the statute consistent with the equal protection clause. 
elicit such uncritical analysis, one can expect little more under present doctrine when other sex-distinguishing laws are challenged. The passive review principle exemplified by Goesaert is, in short, almost a rule that sex distinctions can never violate the equal protection clause. ${ }^{37}$ And, despite a significant shift in attitudes toward sex discrimination, Goesaert has not been overruled.

Some of the reasons for passive review of sex distinctions lie in an accident of history. In the earlier part of this century, the Court, utilizing now discredited standards of substantive due process ${ }^{38}$ invalidated maximum hour laws on the ground that they interfered with the liberty of contract of the employer and employee. ${ }^{39}$ Several states later enacted maximum hour laws limited to women, perhaps hoping that such statutes would better withstand constitutional challenge and believing that protecting some workers was better than protecting none at all. ${ }^{40}$ If this was the theory behind the legislation, it succeeded. In Muller $v$. Oregon, ${ }^{41}$ the Court, sustaining such a law against due process attack, combined arguments based on the physical capabilities of women ${ }^{42}$ and historical patterns of male dominance ${ }^{43}$ to produce its grand conclusion: "she [woman] is properly placed in a class by herself" ${ }^{44}$ as a subject for legislation. That conclusion, never reexamined nor limited in scope by a later opinion ${ }^{45}$ has been used by courts to preserve many different kinds of sex-distinguishing statutes against equal protection attack. ${ }^{46}$ Frequently, those statutes, unlike maximum

37 "Michigan could, beyond question, forbid all women from working behind a bar." Goesaert v. Cleary, 335 U.S. 464,465 (r948) (emphasis added).

${ }^{38}$ For a discussion of these standards by a later Court, see Lincoln Fed. Labor Union v. Northwestern Iron and Metal Co., 335 U.S. 525, 534-37 (1949).

${ }^{39}$ Lochner v. New York, 198 U.S. 45 (1905).

${ }^{40}$ See Kanowitz, Sex-Based Discrimination in American Law III: Title VII of the 1964 Civil Rights Act and the Equal Pay Act of 1963, 20 HAsrrvgs L.J. 305, 306-07 n.8; $\mathrm{II}_{3}$ CoNG. REc. I3,108 (1967) (remarks of Congresswoman Griffiths).

41208 U.S. 4I2 (IgO8).

42 Id. at $42 \mathrm{I}$.

${ }^{43} I d$.

${ }^{44} I d$. at 422 .

${ }^{45}$ See Mengelkoch v. Industrial Welfare Comm'n, 284 F. Supp. 950, 955 (C.D. Cal.), vacated and remanded, 393 U.S. 83 (I968).

${ }^{46}$ See, e.g., Commonwealth v. Welosky, 276 Mass. 398, 4I4, I77 N.E. 656, 664 (x93 r), cert. denied, 284 U.S. 684 (I932) (no violation of equal protection when jury panel is all male); People v. Case, I53 Mich. 98, Iox, II6 N.W. 558, 560 (Ig08) (upholding statute prohibiting saloon keepers from allowing females on their premises); State v. Hunter, 208 Ore. 282, 288, 300 P.2d 455, 458 (r956) (statute barring women from being licensed as professional wrestlers); Heaton v. Bristol, 3I7 S.W.2d 86, 99 (Tex. Civ. App.), cert. denied, 359 U.S. 230 (I959) (state not constitutionally compelled to admit women to all-male branch of a public university system). 
hour legislation which arguably benefits women, have restricted the opportunities of women or denied them an equal share of the benefits and burdens of citizenship. Once a liberal force in constitutional jurisprudence, Muller has changed its form and become the basis for the present uncritical permissive review of sexual distinctions.

The Court's continued use of permissive review for sex distinctions may be based as much on institutional calculations as on historical considerations. The Court might be reluctant to undertake on its own initiative so potentially large, difficult, and politically explosive a task as the reexamination of the legal doctrines surrounding sex roles in society. ${ }^{47}$ Such reluctance might be reinforced by the fact that women are a majority of the population and, unlike racial minorities, can at least theoretically use the vote to protect their interests. However, the proposition that constitutional protection should depend on judicial assessment of a group's political power is, at best, of doubtful validity. ${ }^{48}$ Nonetheless, such practical calculations, combined with the historical background of Muller, may explain why the

${ }^{47}$ This reluctance might be coming to an end. The Court has granted certiorari to cases involving an equal protection challenge to the Illinois law discussed at p. I50r supra, In re Stanley, 45 Ill. $2 \mathrm{~d}$ 132, 256 N.E.2d 8I4 (I970), cert. granted sub nom. Stanley v. Illinois, $9 \mathrm{r}$ S. Ct. 584 (I97x); the Idaho law discussed at p. I50r supra, Reed v. Reed, 93 Idaho 5II, 465 P.2d 635 (1970), cert. granted, 39 U.S.L.W. 3375 (U.S. Mar. I, I97I) (No. 430); and a jury venire list which excluded all women, State v. Alexander, 255 La. 94I, 233 So. 2d 89I (1970), cert. granted sub nom. Alexander v. Louisiana, 39 U.S.L.W. 3375 (U.S. Mar. I, 197I) (No. 5944).

On the other hand, the Court recently summarily affirmed a lower court decision upholding the constitutionality of a state's maintenance of a branch of its public university on a sexually-segregated basis. Williams v. McNair, 39 U.S.L.W. 3388 (U.S. Mar. 8, I97I), aff'g 316 F. Supp. I34 (D.S.C. I970). The lower court had applied the permissive standard of equal protection review.

${ }^{48}$ Political power is a difficult concept for even social scientists to define. Developments I126. Furthermore, many American women either are not aware of or do not care about the inequalities based on sex in the legal structure. Others may have decided that, on balance, they are benefited rather than burdened by current laws distinguishing the sexes, and thus they may oppose the principle that no such distinctions should be allowed. Cf. Kanowitz, Single Girl 296-97. These considerations weaken the argument that women can protect their interests through their political power, however defined. Even if women could use their political power to protect their interests, but do not choose to do so, the minority who feel they are discriminated against still should have a right to constitutional protection. $C f$. Lucas v. Forty-Fourth Gen. Assembly, 377 U.S. 7I3 (I964) (approval by referendum cannot validate otherwise unconstitutional apportionment plan). Finally, as a general matter, judicial decisions based on the political balance in state and national power centers will almost certainly involve inquiry into issues traditionally regarded as "political" and might thus "mar the classical image of judicial impartiality." Note, Hobson v. Hansen: Judicial Supervision of the Color-Blind School Board, 8I HaRv. L. REv. I5II, I524 (I968). 
Court has not yet reexamined the constitutional status of sex discrimination under the equal protection clause.

\section{B. The Possibility of a Stricter Standard of Review}

Opponents of a new constitutional amendment for "equal rights" argue that the Court can be persuaded to eliminate irrational sex distinctions through the equal protection clause. ${ }^{49}$ The growing public awareness of and opposition to sexual discrimination, and the evidence of congressional support for reform embodied in Title VII, ${ }^{50}$ might well convince the Court that it is time to reexamine its permissive review standard..$^{51}$

One possibility for a more active standard of review might lie in the fundamental interest doctrine. Statutes classifying by sex, like statutes classifying by any other trait, are subject to a strict standard of equal protection scrutiny when fundamental interests are impinged. ${ }^{52}$ For example, several recent decisions, which invalidated sentencing discriminations on the basis of $\operatorname{sex}^{53}$ can be rationalized in terms of equal protection doctrine by arguing that the statutes involved abridged the fundamental interest in freedom from incarceration without sufficient justification.

However, the utility of such an approach depends on the willingness of the courts to expand the concept of "fundamental interest"; recent judicial treatment of the fundamental interest doctrine casts doubt on its usefulness for eradicating sex discriminations. In Dandridge v. Williams, ${ }^{54}$ the Court specifically excluded from strict scrutiny under the fundamental interest doctrine "state regulation in the social and economic field, not affecting freedoms guaranteed by the Bill of Rights." 55 Although the parameters of fundamental interest described by Dandridge are far from clear, the Court cited Goesaert v. Cleary ${ }^{56}$ as an example of excluded "economic and social regulation," $5 \tau$ indicating that one of the most important areas of sex discrimination, employment, is presumptively immune from attack under a fun-

49 See Report of the Commitee on Civil and Political Rights to the President's Commission on THE Status of WomeN 36-37 (1963); Hearings 74 (testimony of Professor Freund); Report 79-80.

so See note 2I supra.

51 See note 47 supra.

52 See Kanowitz, Constitutional Aspects of Sex-Based Discrimination in American Law, 48 NEB. L. REV. I3I (Ig68).

${ }^{53}$ United States ex rel. Robinson v. York, 28I F. Supp. 8 (D. Conn. 1968); Commonwealth v. Daniel, 430 Pa. 642, 243 A.2d 400 (I968), noted in 82 Harv.

L. REv. 92 I (I969). But see State v. Wark, 266 A.2d 62 (Me. I970).

54397 U.S. 47 I (1970).

55 Id. at 484 .

${ }^{56} 335$ U.S. 464 (I948); see pp. I503-04 supra.

57 397 U.S. at 485 . 
damental interest theory. Even if Dandridge were not a roadblock to establishing a "fundamental interest" in employment, the doctrine would not be a particularly reliable tool to reach a wide variety of sex discriminations due to the Court's rather ad hoc articulation of fundamental interests. ${ }^{58}$ Finding a fundamental interest in one area, such as employment, would in no way guarantee a similar finding in such unrelated areas as property and inheritance law.

In view of these difficulties, the suspect classification approach would seem more promising as the basis for the kind of sweeping attack on sex discrimination which even the opponents of an amendment agree is necessary. Although the primary concern of the framers of the fourteenth amendment was to eliminate racial discrimination, ${ }^{59}$ the Court has applied to legal classifications made on the basis of national origin or lineage a standard of equal protection review substantially equivalent to that given racial distinctions. ${ }^{60}$ While judicial standards for determining which classifications are "suspect" have not as yet been clearly articulated, the Court would be justified in applying to sex classifications the same standard it now applies to racial classifications if the similarities between the two were compelling.

The similarities between race and sex discrimination are indeed striking. ${ }^{61}$ Both classifications create large, natural classes, membership in which is beyond the individual's control; ${ }^{62}$ both are highly visible characteristics on which legislators have found it easy to draw gross, stereotypical distinctions. Historically, the legal position of black slaves was justified by analogy to the legal status of women. ${ }^{63}$ Both slaves and wives were once subject to the all-encompassing paternalistic power of the male head of the house. $^{64}$ Arguments justifying different treatment for the sexes on the grounds of female inferiority, need for male protection, and happiness in their assigned roles bear a striking resemblance to the half-truths surrounding the myth of the "happy slave." 05 The historical patterns of race and sex discrimination have, in many instances, produced similar present day results. Women and blacks, for example, hold the lowest paying jobs in industry,

${ }^{5}$ See Developments $\mathrm{x}$ 30-3I.

"59 See McLaughlin v. Florida, 379 U.S. I84, r92 (1964); Developments II25.

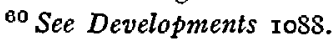

${ }^{61}$ See A. Montagu, Man's Most Dangerous Mytr x8I-84 (4th ed. I964);

G. Myrdal, AN Adrerican Ditemara ro73-78 (2d ed. x962).

${ }^{62}$ See Crozier, Constitutionality of Discrimination Based on Sex, 15 Boston

U.L. Rev. 723, 728 (1935). See also Report 79.

${ }^{63} \mathrm{G}$. MYrdal, supra note $6 \mathrm{r}$, at 1073.

${ }^{64}$ Id. at ro73-75.

${ }^{65}$ See A. Montago, supra note $6 x$, at $\mathrm{x} 8 \mathrm{x}$. 
with black men doing slightly better than white women. ${ }^{66}$ After an examination of such evidence, Gunnar Myrdal concluded: ${ }^{67}$

In the final analysis, women are still hindered in their competition by the function of procreation; Negroes are laboring under the yoke of the doctrine of unassimilability which has remained although slavery is abolished. The second barrier is actually much stronger than the first in America today. But the first is more eternally inexorable.

The factual similarities between race and sex discrimination are reinforced by broader concerns. Through a process of social evolution, racial distinctions have become unacceptable. The old social consensus that race was a clear indication of inferiority has yielded to the notion that race is unrelated to ability or performance. Even allegedly rational attempts at racial classification are now generally rejected outright. The burden of showing that these attempts are based on something other than prejudice is enormous.

There are indications that sex classifications may be undergoing a similar metamorphosis in the public mind. Once thought normal, proper, and ordained in the "very nature of things," sex discrimination may soon be seen as a sham, not unlike that perpetrated in the name of racial superiority. Whatever differences may exist between the sexes, legislative judgments have frequently been based on inaccurate stereotypes of the capacities and sensibilities of women. In view of the damage that has been inflicted on individuals in the name of these "differences," any continuing distinctions should, like race, bear a heavy burden of proof. One function of the fourteenth amendment ought to be to put such broad-ranging concerns into the fundamental law of the land..$^{68}$

There does exist, then, a factual and moral base from which the Court could conclude that race and sex discrimination should receive substantially similar equal protection treatment. Yet the analogy has its limits, and sex discrimination, if it is to be constitutionally attacked, must be treated as a problem in its own right. In particular, women may differ from men in ways which might rationally be reflected in statutes. For example, women

${ }^{66}$ See N.Y. Times, Jan. 3I, I97I, $\$$ I, at 50, col. 3 .

${ }^{67} \mathrm{G}$. MYRDAL, supra note $6 \mathrm{r}$, at I078. This quote comes from the same work as that on which the Supreme Court relied for information about race relations in Brown v. Board of Education. See 347 U.S. 483, 494-95 n.II (x954).

${ }^{88} \mathrm{Cf}$. Developments II74 n.6I (as the truth of the proposition that biological differences between the sexes correlate with performance is drawn into question, all sexual classifications become more suspect). 
appear to live longer on the average and exclusively possess the procreative function. ${ }^{69}$ Some alleged differences ${ }^{70}$ may turn out, on further investigation, to be products of environment and training rather than of immutable physiology. Until further studies are made, however, the possibility that the apparent differences are real must be acknowledged. Laws classifying on the basis of such apparent differences between the sexes might be upheld, even though if similar physiological differences were found to exist between the races, ${ }^{\mathbf{1 1}}$ the historical background of the fourteenth amendment, concerned as it is with the special stigma of slavery, would probably not permit these differences to be taken into account for purposes of legal classification. Whatever the differences between race and sex discrimination, however, racial precedents, with their highly articulated jurisprudence, do provide a good starting point for analysis of sex distinctions.

If the Court decides to adopt an active review standard for sex, the state will be required to make a substantial showing that a sexual distinction is justified by some important state interest. Under such a standard, laws based on unsupported contentions about women's proper role in society should fall. ${ }^{72}$ In two easily identifiable areas, however, the state will often be able to make a colorable showing which will require detailed judicial analysis. First, the state may argue that some legislation is based on aggregate statistical differences between men and women. Statistically, for example, women live longer than men, perhaps justifying lower life insurance premiums for women in a statesupported insurance program; similarly, laws which aim to protect women by prohibiting their employment in jobs requiring the lifting of heavy weights ${ }^{73}$ may be based on an aggregate statistical judgment that women are physically weaker than men. Second, some laws, such as those requiring separate bathrooms and

${ }^{69}$ Six states plus Puerto Rico prohibit the employment of pregnant women at some stage of their pregnancy. See, e.g., N.Y. LABor LAw \$ 206-b (McKinney I965).

${ }^{70}$ See Tiger, Male Dominance? Yes, Alas. A Sexist Plot? No. N.Y. Times, Oct. 25, 1970, $\$ 6$ (Magazine), at 35 .

${ }^{71}$ See Jensen, How MIuch Can We Boost I.Q. and Scholastic Achievement?, 39 HaRv. Educ. Rev. I (xg69), in which the author, backed by substantial empirical data, argues that genetic rather than environmental factors predominate in explaining the differences in performance by whites and nonwhites on standardized intelligence tests. The Jensen article has evoked both a scientific and political counterattack. See Edson, Jensenism, n.: The Theary that I.Q. is Largely Determined by the Genes, N.Y. Times, Aug. 3x, 1969, \$ 6 (Magazine), at ro.

${ }^{72}$ See, e.g., Reed v. Reed, 93 Idaho 5II, 465 P.2d 635 (1970), cert. granted, 39 U.S.L.W. 3375 (U.S. Mar. I, I97I) (No. 430) (statute apparently based on the unverified assumption that women are less capable financial managers than men).

${ }^{73}$ See, e.g., N.Y. LABOR LAw \$ 3 II (McKinney I965). 
dormitories, may reflect deeply ingrained notions of personal bodily privacy. ${ }^{74}$

The difficulty with statutes based on aggregate statistical judgments, of course, is that, while they may provide greater administrative efficiency and may benefit many members of the class, they may also cause substantial harm to individuals who differ from the statistical norm. One way of analyzing the problem of aggregate legislation is to ask whether the characteristics of the class important to the determined purposes of the statute match the characteristics of the class actually designated by the statute. ${ }^{75}$ Consider a hypothetical statute prohibiting women from drinking alcohol, whose purpose is determined to be the prevention of public drunkenness. ${ }^{76}$ Unless the state can show that all women who drink become public drunks, the characteristics of the class important to the purpose of the statute (public drunks) do not match perfectly the characteristics of the class actually designated by the statute (women who drink).

The question for the Court, then, is what degree of mismatch between the important class and the designated class it will tolerate. Some commentators can be interpreted as urging that no degree of mismatch be tolerated, because all laws can be rewritten asexually. ${ }^{77}$ Thus, a maximum weight-lifting restriction, to be valid, would have to refer to the muscular capacity of an

\footnotetext{
${ }^{74} \mathrm{~A}$ further problem area under a strict standard of review would involve benign quotas justified as necessary to remedy the past effects of discrimination against women. The outlines of the problem are unclear, however, since the Supreme Court has not yet ruled on similar laws in the racial area. See Developments Iro6-I2 for a discussion of the possible permissible use of racial criteria when the purpose of the state action is "benign."

${ }^{75}$ Inquiring into the relationship between the "important class" and the "designated class" is merely another way of asking if the class specified is underinclusive or overinclusive when considered in light of the purpose of the statute. See id. at I082-87. The "important/designated" formulation is proposed because it forces a precise definition of the classes of persons being compared and because the idea of a perfect or non-perfect match which flows from it is more useful for dealing with the idea of statistical aggregate characteristics. In particular, it may provide two "classes" for comparison if a court or commentator wishes to set up a cut-off point; for example, we might wish to permit only those laws based on an $80 \%$ or greater match.

${ }^{70}$ This assumption should not be taken to imply that the determination of legislative purpose is a simple matter. To the contrary, the willingness of the Court to attribute purpose broadly or narrowly will have much to do with the outcome of the matching analysis. For a general discussion of the difficulties of purpose attribution in the equal protection context, see $i d$. at 1077-87. When purpose is used in this Note, however, it is asumed that the Court has already gone through the difficult process of determining it.

${ }^{77}$ See Kanowitz, Constitutional Aspects 138; Murray \& Eastwood, Jane Crow and the Law: Sex Discrimination and Title VII, 34 Geo. WaSH. L. Rev. 232, 240-41 (1965); cf. Hearings 325 (testimony of N.Y.U. Law School Professor Norman Dorsen).
} 
individual, as measured in some scientific way. Such a position has generally been called "functional analysis" because it emphasizes the function or purpose for which the statute was allegedly passed; the "function" of a weight-lifting restriction is protecting those workers who would be injured by more than a given amount of exertion. ${ }^{78}$

The requirement that all statutes be written asexually is attractive because it eliminates the difficulties of evaluating sophisticated medical, sociological, and actuarial theories of aggregate differences between the sexes. ${ }^{79}$ It is also attractive because it would represent the highest degree of societal commitment to the ideal of legal sexual equality. ${ }^{80}$

It can be argued, however, that a principle which permits no deviation from a perfect match would impose unreasonable administrative costs in some cases. ${ }^{81}$ The logical outcome of

${ }^{78}$ One state apparently has rewritten its weight-lighting restriction along functional lines. See Hearings 172 (testimony of University of New Mexico Law School Professor Leo Kanowitz).

${ }^{79}$ Such difficulties are probably not insuperable. See, e.g., Shpritzer v. Lang, I7 App. Div. 2d 285, 234 N.Y.S.2d 285 (1962), aff'd, I3 N.Y.2d 744, 19I N.E.2d 9r9, 24I N.Y.S.2d 869 (1963), in which the court refuted a contention that physical differences justified the exclusion of women from promotional opportunities in the police department by noting that women perform satisfactory work in high police positions in other countries. For an example of complex factual evaluation in racial discrimination, see Hobson v. Hansen, 269 F. Supp. $40 \mathrm{r}$ (D.D.C. I967), aff'd sub nom. Smuck v. Hobson, 408 F.2d I75 (D.C. Cir. Ig6g).

${ }^{80} \mathrm{~A}$ requirement of a perfect match would require reexamination of previous Supreme Court decisions in the area of sex discrimination. See, e.g., Hoyt v. Florida, 368 U.S. 57 (Ig6I). The important class for the Hoyt statute in the Court's analysis seemed to be mothers, but all women (the designated class) were optionally exempted from jury duty, an obvious mismatch. It could even be argued that the "important" class for the Hoyt statute should be those of either sex for whom jury duty would be a hardship, since it is difficult to see why a mother who can easily afford a baby sitter should be optionally exempt from jury duty while a man who must take a substantial reduction in pay to serve is not. See Kanowitz, Single Girl 323-26; of. 5I MINN. L. Rev. 552, 556 (1967). This broader description of the important class (involving a problem of purpose attribution, see note 76 supra) would increase the magnitude of the mismatch. It could be argued, however, that the statute in Hoyt was designed to protect children from harm due to their mother's enforced absence. Even if the statute's important class were "parents whose absence would cause detriment to the child," there would still be a mismatch, for in some cases (as where the child's only surviving parent is his father) the absence of the male parent could be just as detrimental to the child.

81 "Administrative feasibility" seems to be one reason the Court did not require the exemption in Hoyt to be more narrow. See 368 U.S. 57, 64 (196r) ; cf. Wells v. Civil Serv. Comm'n, 423 Pa. 608, 225 A.2d 554, cert. denied, 386 U.S. 1035 (I967) (administrative costs cited as a reason that women, who composed a far smaller share of the applicants, could be burdened with an oral examination requirement for police promotion while men were not); Reed v. Reed, 93 Idaho 5Ir, 465 P.2d 635 (1970), cert. granted, 39 U.S.L.W. 3375 (U.S. Mar. I, 197I) (No. 430) (court cited reduction in litigation achieved by a statute which gives 
such a view is to urge a balancing test, allowing a less-thanperfect match when administrative inconvenience outweighs the individual interests invaded. ${ }^{\$ 2}$ While administrative cost may seem a plausible reason for allowing certain types of sex-distinguishing statutes to be maintained, the balancing process is, in fact, fraught with difficulty.

The problems with the balancing approach can be seen by analyzing an analogous racial situation. In Korematsu v. United States ${ }^{83}$ the Court upheld the wartime exclusion of all JapaneseAmericans from certain areas of the western United States because of a supposed threat of espionage by some JapaneseAmericans. In that case the important class - those who presented a threat of espionage - obviously did not match the designated class - all Japanese-Americans. However, in light of the presumed threat of imminent foreign invasion, the timeconsuming process of individual examination might have thwarted the purported national security purpose of the exclusion. ${ }^{84}$

Korematsu demonstrates the pitfalls of attempting to balance important personal rights against administrative costs. It is often difficult for courts to investigate adequately the alleged administrative difficulties in identifying members of the important class. Many people now feel, for example, that the asserted administrative difficulty of ferreting out those Japanese-Americans who were a threat to national security was grossly exaggerated by the government and could not justify such a gross mismatch. ${ }^{85}$ Korematsu also demonstrates the extreme difficulty of knowing what weight should be given to administrative costs, even when convincingly shown, when balanced against important individual rights. There may be a temptation in the heat of the alleged "administrative crisis" to give less easily dramatized personal rights short shrift. Thus, in retrospect, Korematsu involved 'an unfortunate discounting of personal rights, leading to unnecessary human suffering and substantial political embarassment after the "emergency" had passed. While not as dramatic as Koremat$s u$, it may be just as difficult to strike a satisfactory balance between administrative costs and personal deprivation in sex discrimination cases.

It is impossible within the scope of this Note to survey every

males an absolute preference over females in estate administration contests as a reason the statute is not constitutionally infirm).

${ }^{82} \mathrm{Cf}$. Developments Iro3 (suggesting balancing approach in racial context).

${ }^{83} 323$ U.S. 2 I4 (I944).

${ }^{84}$ See Developments I102.

${ }^{85}$ See A. Girdner \& A. Loftis, The Great Betrayal: The Evacuation of the Japanese-Americans During Worid War II I6-32 (Ig6g); B. Hosokawa, NISET: THE QUIET AMERTCANS 292-98 (I969). 
category of sex-distinguishing statute for which administrative cost might be offered as justification. But in making the choice between a balancing test and a perfect match requirement, two factors peculiar to sex-distinguishing laws should be taken into account. First, few of the administrative efficiency goals which sexdistinguishing statutes are designed to reach would be seriously compromised if sex could not be used as a basis for classification. Many laws justified by the alleged efficiency of a sexual test could be replaced by non-sexual tests which would create a perfect match at little or no additional cost. For example, statutes which place weight-lifting restrictions solely on women seem designed to protect physically weak workers. A visual survey of job applicants, male and female, would appear to be just as useful in distinguishing those who are too fragile for the employment involved. Second, many of the laws which have at best a questionable efficiency rationale impinge on important individual rights such as employment and jury service. Thus, the Court might well conclude that because the bulk of sex-distinguishing laws have dubious administrative justifications and because they often impinge on important individual rights, a "perfect match" standard, permitting no administrative justification for ill-fitting sex classifications, is called for.

The finding of a mismatch, however, need not always mean that the statute must fall; a court might simply extend the coverage of the statute to the excluded sex, thereby eliminating the suspect classification which triggered active review. For example, the coverage of the weight-lifting statute previously mentioned might be extended from women to all workers, whether male or female. $^{88}$

In choosing between extension or elimination of the statute, a court must weigh the general interest in retaining some statutory provision against a judicial reluctance to extend coverage without legislation. ${ }^{87}$ The court's reluctance might be eased by considering the historical reasons which limited many early wage and hour laws to women. As noted earlier, ${ }^{88}$ many protective laws were enacted against the background of now discredited standards of due process which invalidated such protections for men. It is, therefore, a reasonable inference that the enacting

${ }^{86}$ Cf. Levy v. Louisiana, 39 I U.S. 68 (1968), in which the Court held that a state statute which barred illegitimate but not legitimate children from recovering in tort for the wrongful death of their mother violated the equal protection clause. The Court struck out the specific exception barring illegitimate children, but retained the general right to recover.

${ }^{87}$ Developments $\mathrm{x} \mathrm{x} 36-37$.

${ }^{88}$ See p. 1504 supra. 
legislature, in some cases, would have extended the protection to men had its constitutional power not been limited. ${ }^{89}$

Of course, extension of these laws rather than elimination in toto might bring about economic dislocations. ${ }^{90}$ In some cases, as, for example, when a statute prohibits women from engaging in a certain occupation, extension would be ludicrous because it would have the effect of eliminating the occupation. In other cases, the pay of workers who depend on substantial amounts of overtime might be drastically lowered if the working hours of male laborers were suddenly limited by abolishing compulsory overtime. Similarly, across-the-board extension to men of minimum wage laws now limited to women might drive some producers out of business or cause some male laborers to lose their jobs to automation. In evaluating the remedial alternatives of extension or elimination, a court must consider whether the legislature is better equipped to deal with the ramifications of extension. Courts may prefer simply to eliminate these laws rather than extend them. An alternative would be for courts to eliminate the laws but delay relief for a reasonable period ${ }^{91}$ to allow legislatures to redefine legal relationships. ${ }^{92}$

In addition to the problem of aggregate legislation, a second area of concern involves those statutes which appear to have been enacted to protect notions of personal privacy surrounding the sexual organs or exposure of the body. ${ }^{93}$ State action, for example, may mandate sexually separate dormitories at a public university or restrooms in public buildings. Such statutes might be protected from the sweep of active review by resurrecting the constitutional cadaver of "separate but equal." ${ }^{94}$ In such cases, the law might

${ }^{89} \mathrm{Cf}$. Kanowitz, Constitutional Aspects I 70.

${ }^{90}$ See Indritz, Book Review, 4 FaMmLY L.Q. 6, 9-1o (1970).

${ }^{91}$ Brown v. Board of Educ., 349 U.S. 294 (I955), in the racial area and White v. Crook, 251 F. Supp. 40I (M.D. Ala. 1966), in the sexual area both provide examples of delayed equal protection relief.

${ }^{92}$ For example, a state might enact a voluntary overtime law for workers of both sexes; see Letter from Professor Leo Kanowitz, University of New Mexico Law School, to Senator Birch Bayh, Nov. 6, 1970, at $44-15$, on file at the Harvard Law Review.

${ }^{93}$ For an argument that privacy might provide legitimate exceptions to even a "perfect match" standard, see Hearings 304 (testimony of Professor Emerson).

${ }^{94}$ Another approach to the problem is to treat sexual bodily privacy as a matter of strong consumer preference. For example, despite Title VII of the Civil Rights Act of 1964 , which forbids employment discrimination on the basis of sex, the occupation of washroom attendant for women's restrooms could be limited to females. Such a limitation seems acceptable because it does not brand either sex as incompetent to perform the job, and is a matter of strong consumer preference. See Developments in the Law-Employment Discrimination and Title VII of the Civil Rights Act of 1964, 84 HARv. L. REv. xrog, Ix85-86 (I971). A standard of evaluation based on consumer preferences may be acceptable in a statutory con- 
be upheld if the facilities provided for one sex were tangibly and intangibly equal to those provided for the other. ${ }^{95}$ Brown $v$. Board of Education ${ }^{96}$ does not preclude such a doctrine in the sexual privacy area. Brown seems to have been based on the idea that separate was inherently unequal because it was a sign to all concerned that one race was socially inferior to the other. ${ }^{97}$ Separation of facilities indicated that whites did not want to associate with blacks. In contrast, there has never been any indication that men have wished to avoid intimate contact with women on a daily basis. Therefore, the separation of restrooms and the like by sex, unlike separation by race, has no automatic implication of inferiority. ${ }^{98}$

Incorporating the principle of "separate but equal" as an exception to active review would permit the state to retain the sexually segregated restrooms and dormitory facilities associated with notions of personal bodily privacy. Its rationale, however, would be strictly limited to those facilities which involve potential exposure of intimate parts of the body. No such potential exists in schools, ${ }^{99}$ state-run public accommodations, or other facilities where sexual segregation may be traditional but is not motivated by notions of bodily privacy.

Even in those facilities to which "separate but equal" would apply, it should remain open to plaintiffs of either sex to establish that the separate facilities are not "equal" or that some harm of

text but it provides too ephemeral a basis for a constitutional test. Consumer preferences are difficult for courts to measure and are capable of rapid shifts. Furthermore, the fact that a law is preferred by large numbers of people does not mean it is constitutionally valid.

${ }^{95}$ Cf. McLaurin v. Oklahoma State Regents, 339 U.S. 637 (I950); Sweatt v. Painter, 339 U.S. 629 (1950). Compare Heaton v. Bristol, 317 S.W.2d 86 (Tex. Civ. App. 1958), cert. denied, 359 U.S. 230 (1959), and Allred v. Heaton, 336 S.W.2d 25I (Tex. Civ. App.), cert. denied, 364 U.S. 5I7 (Ig60) (women denied admission to all-male branch of state university because same university had equivalent, all-female facilities), with Kirstein v. Rector \& Visitors of the Univ. of Va., 309 F. Supp. I84 (E.D. Va. I970) (women entitled to admission to previously all-male branch of state university because it was best facility in whole system).

${ }^{98} 347$ U.S. 483 (1954).

${ }^{97}$ See Black, The Lawfulness of the Segregation Decisions, 69 YaLE L.J. 42I, $424(1960)$.

${ }^{98}$ Murray \& Eastwood, supra note 77 , at 240 ; of. Developments ri27 (no "badge of opprobrium" attaches to sexual classification).

${ }^{89}$ On the constitutional problems of coeducation, see Note, The Constitutionality of Sex Separation in School Desegregation Plans, 37 U. CHr. L. Rev. 296 (1970).

The Supreme Court recently summarily affirmed a lower court decision upholding the constitutionality of state mandated sexually separate branches of a public university. Williams v. McNair, 39 U.S.L.W. 3388 (U.S. Mar. 8, 197r),

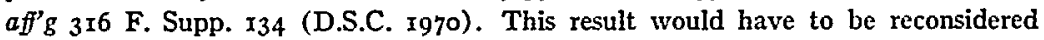
in the event that sex were declared a "suspect classification." 
substantial magnitude results from the segregation itself. Courts would have to make such determinations on a case-by-case basis. If inequality of facilities were established, a court could order either equalization or integration. If harm from the very fact of segregation were shown, a state might be required to provide sexually integrated facilities for those who want them (as by rearranging existing dormitory space so that students could freely choose between all-male, all-female, and mixed housing) or be forbidden from distinguishing facilities by sex at all.

While there is strong justification for the Court to adopt an active standard of review for sex distinctions, precedent, the difficulties of the task, and the political dangers involved may discourage such a bold judicial initiative. ${ }^{100}$ Congress might therefore conclude that legislative action is needed to eliminate sex discrimination.

\section{Congressional Action - Specific Legrslation versus Constitutronal Amendment}

If judicial action to remedy the evils of sex discrimination seems unlikely in the near future, ${ }^{101}$ Congress should either enact legislation or initiate the constitutional amendment process. In choosing between these alternatives, Congress must carefully evaluate the advantages and disadvantages of each; the choice between them undoubtedly will influence the scope of substantive reform.

\section{A. Legislation}

If reformers want to sweep away the legal roadblocks to sexual equality, congressional legislation will have to reach deep into the well of state law, where most legal discrimination lies. Such areas as property, criminal, and family law are traditionally regarded as reserved to the states. Hence the question is one of congressional power to legislate in these areas; Congress has two

${ }^{100}$ But see note 47 supra.

${ }^{101}$ Opposition to a constitutional amendment is generally predicated on the assumption that the Court will evolve more rigorous standards for evaluating sex distinctions under the equal protection clause. See, e.g., Report 8r. Such standards would eliminate most of the benefits intended to be achieved by a new amendment (except for the possible increase in congressional power to legislate against sex discrimination in areas otherwise reserved to the states, see pp. I5I7-I 8 infra) and would probably render it undesirable. See generally Report 80-82. This Note henceforth proceeds on the assumption that in the reasonably near future there will be little change in the Court's current equal protection standards regarding sex discrimination and evaluates the alternative reform devices available to Congress. 
buckets with which it might plumb the well: the commerce clause and section five of the fourteenth amendment.

While the Congress has successfully exercised the commerce power to provide some remedy for sexual discrimination in employment, ${ }^{102}$ and while recent judicial decisions have imposed few limits on the scope of the commerce power, ${ }^{103}$ there is serious question whether Congress can reach the remaining problems through the commerce clause. Inheritance, marriage, and divorce are so tenuously related to interstate commerce ${ }^{104}$ that the validation of congressional attempts to control them under the commerce clause would effectively remove all limits on the power of the federal legislature. The courts might well refuse to go so far; ${ }^{105}$ Congress too might hesitate to exercise such power. ${ }^{106}$

The other possible source of congressional power is section five of the fourteenth amendment. Until recently, a number of commentators felt that under this clause Congress could go beyond judicially determined violations of equal protection and itself perceive and remedy discriminations in state law. ${ }^{107}$ Under this theory, for example, Congress could determine that state inheritance laws discriminate against women and could provide a corrective mechanism. This Term, however, in Oregon v. Mitchell, ${ }^{108}$ the Supreme Court struck down a congressional statute enacted under this theory which lowered the voting age to eighteen in all state and local elections. ${ }^{109}$ One of the opinions in Mitchell, relying on an analysis of the legislative history of the fourteenth amendment, indicated that Congress' power to invade areas reserved to the states is greater when the evil legislated against is race discrimination than when it seeks to remedy any

${ }^{102}$ See note 2 s supra.

${ }^{103}$ See, e.g., Heart of Atlanta Motel v. United States, 379 U.S. 24I (I964); Katzenbach v. McClung, 379 U.S. 294 (1964).

${ }^{104}$ Cf. Northern Sec. Co. v. United States, I93 U.S. I97, 402 (rgo4) (Holmes, J., dissenting) (commerce clause does not give Congress power to regulate marriage and divorce).

${ }^{105} C f$. United States v. Five Gambling Devices, 346 U.S. 44r, 449 (opinion announcing the judgment of the Court interprets statute so as to avoid "serious question" as to scope of congressional power under commerce clause).

${ }^{108}$ See excerpts from the congressional committee hearings on the public accommodations sections of the Civil Rights Act of 1964 , quoted in G. GuNTher \& N. Dowling, Cases and Materials on Constitutronat Law 327-35 (8th ed. I97o).

${ }^{107}$ See Cox, The Supreme Court, ro65 Term, Foreword: Constitutional Adjudication and the Promotion of Human Rights, 80 HARv. L. REv. 91, 99-ro8 (1966) (discussing the implications of Katzenbach v. Morgan, 384 U.S. 641 (I966)); Developments 1073-76.

${ }^{108} 9$ I S. Ct. 260 (r970).

109 The Court upheld the congressional lowering of the voting age in all national elections, however. 
other equal protection problem. ${ }^{110}$ Another opinion suggested that congressional power is limited to legislating in areas where there is a pre-existing (i.e., court-determined) violation of equal protection. ${ }^{111}$ While these opinions expressing a restrictive view of congressional power to pass remedial section five legislation in an area like sex discrimination represented the views of only four justices, the opposite and expansive interpretation of congressional power under section five also failed to persuade a majority of the Court. It is probable, however, that the "swing" justice, Justice Harlan, leans toward a restrictive view. ${ }^{112}$ The Court's decision in Mitchell has made section five of the fourteenth amendment at best a tenuous basis for expansive congressional action.

If the problems of congressional power can be overcome, however, the advantages of a legislative approach must be recognized. First, and most important, legislation can resolve particular problems without any obligation to resolve the next problem in precisely the same way. Second, legislation is able to reconcile the principle of no sex discrimination with competing values such as privacy and claimed benefits of distinction. For example, all women are not in favor of invalidating laws which they feel give them special protection against exploitation by employers. ${ }^{113}$ The legislative process leaves open the possibility of eliminating some discriminatory laws without affecting these. Finally, legislation can easily be modified in the light of experience.

The extent to which these advantages will be realized, of course, will depend on the type of statute Congress chooses to enact. If it uses a broad, generally worded statute, ${ }^{114}$ much of the

${ }^{110}{ }_{91}$ S. Ct. at 266-67 (Black, J.).

${ }^{111}$ Id. at $35^{\circ}$ (Stewart, J., Burger, C.J., \& Blackmun, J., concurring in part and dissenting in part).

112 Justice Harlan concurred in the result as to local elections on other grounds, and did not reach the question of the limits of congressional power under section five because he found the contention that members of the I8- to 2 I-year-old age group were discriminated against by being denied the vote "little short of fanciful." Id. at 309. He did indicate that "[t]he history of the Fourteenth Amendment may well foreclose the possibility that $\$ 5$ empowers Congress to enfranchise a class of citizens so that they may protect themselves against discrimination forbidden by the first section," $i d$., before deciding he did not have to decide the issue. It should also be noted that Justice Harlan dissented in Katzenbach $v$. Morgan, 379 U.S. 294 (1964), on which the theory of expansive congressional power under section five had been based.

${ }^{113}$ See, e.g., Hearings 3 I (testimony of union leader Mrs. Myra Wolfgang). This does not imply that if the Court found protective labor legislation limited to women only to be unconstitutional, a dissenting majority of women should be able to restrict such constitutionally protected rights.

${ }^{114}$ E.g., "Neither the United States nor any state shall deny any citizen of the 
specificity which is the peculiar advantage of the statutory approach will be left to the courts. If Congress chooses to utilize more detailed statutes, ${ }^{115}$ however, the specificity of the statutory approach will be preserved, but the burden on a busy Congress will be great and many discriminations which affect only small numbers of people will inevitably escape remedy.

\section{B. Constitutional Amendment}

The most compelling argument for a constitutional amendment is that, unlike a statute, its ability to reach deep into the well of state law is unquestioned. Potentially, it can sweep away every vestige of legal sex discrimination.

An amendment has other advantages as well. It is permanent, highly symbolic, ${ }^{116}$ and guarantees a hearing in the courts for everyone who claims to be oppressed by even the most obscure and seemingly trivial legal sexual distinctions. A properly worded enabling clause could also serve to increase the scope of congressional power to legislate in areas otherwise reserved to the states. ${ }^{117}$

In the amendment's very sweep and power, however, lie its most serious weaknesses. Unlike a statute, it cannot distinguish as easily between those laws we wish to eliminate and the few we may wish to keep. An amendment delegates to a single individual the power, through the courts, to work out the details of its governing principle, even if his views conflict with the desires of a majority of those affected. The majority of women may, for example, favor retaining sex-distinguishing laws which restrict their working conditions or protect their privacy. A single dissenting member of the class would, under an amendment, have

United States the same right to buy, lease, sell, inherit and possess property as is granted to male citizens thereof." Cf. $4_{2}$ U.S.C. $\$$ I982 (I964), which the Court in Jones v. Alfred H. Mayer Co., 392 U.S. 409 (I968), interpreted to bar private discrimination on the basis of race in the sale and rental of housing. The Jones Court, however, upheld $\$ 1982$ on the basis of the thirteenth amendment which, as interpreted, gave Congress the power to condemn private action preserving the "badges and incidents" of slavery. A statute with a reach equivalent to $\$ 1982$ could not be passed under the fourteenth or any of the proposed amendments, as they are limited to barring discrimination by state action.

${ }_{115}$ E.g., "No preference shall be given to any party to an estate administration contest on the basis of sex." Such a statute would be designed to supercede the Idaho statute, described at p. r5or supra, which was held valid against equal protection attack in Reed v. Reed, 93 Idaho $5 \mathrm{rr}, 465$ P.2d 635 ( 1970 ), cert. granted, 39 U.S.L.W. 3375 (U.S. Mar. I, I97I) (No. 430).

${ }^{116}$ Even those who oppose an amendment concede it may have symbolic value. See Letter from Harvard Law School Professor Paul Freund to Senator Birch Bayh, Oct. 21, 1970, on file at the Harvard Law Review. It should be noted, however, that a broad statute can also have strong symbolic value.

${ }^{117}$ See pp. 1521-22 infra. 
the potential power to invalidate such laws. In causes of action brought by black plaintiffs under the fourteenth amendment, there has been the tenable presumption that the results achieved were acceptable to the vast numbers of people similarly situated. In the area of protective labor legislation, at least, no such presumption can exist for women. ${ }^{118} \mathrm{~A}$ broadly worded statute, of course, would also delegate to a single disaffected individual the power to achieve results out of proportion to his political power. If the results of such private litigation are displeasing, however, Congress can amend the statute. Correcting the results of individual litigation under an amendment is far more difficult.

Some have claimed that ratification of a new amendment dealing solely with sex discrimination might discourage the Court from expanding the equal protection doctrine of "suspect classifications" to new areas. ${ }^{119}$ Their argument seems to be that if Congress takes positive action to make sex a suspect classification, the Court will conclude that it need not expand the equal protection clause on its own initiative; whenever expansion becomes desirable, political pressures will force Congress to expand constitutional protection through the amendment process. There does not, however, seem to be any justification for the judiciary to restrict its development of constitutional doctrine merely because the legislature has taken steps toward similar ends. Just as the other branches of government should not view judicial action as abrogating their responsibility for constitutional interpretation, ${ }^{120}$ the Court should not view the actions of other branches as abrogating its primary responsibility in the field. Furthermore, Congress could minimize the risks of a restrictive view governing in this particular case by specifying in the amendment's legislative history, or perhaps in the amendment itself, that ratification should not be interpreted as restricting the articulation of further "suspect classifications."

A possible compromise blending the benefits of constitutional amendment and the benefits of legislation can be suggested. Assuming that Congress does not want to burden an amendment with specific exceptions, ${ }^{121}$ yet wants to retain the power to exempt certain laws from the operation of the amendment, a proposal can be developed encompassing both goals. A modified constitutional amendment might give Congress the power to exempt by statute specific state and federal laws from the force of

\footnotetext{
${ }^{118}$ See note II3 supra.

${ }^{110}$ See Report 82.

I20 See Goldberg \& Dershowitz, Declaring the Death Penalty Unconstitutional,

83 HaRv. L. REv. I773, I806-I3 (I970).

121 See pp. 1522-23 infra.
} 
the amendment. The advantage of such a modified amendment is that, like the more generally proposed versions, it would reach every aspect of discrimination. And while it would permit exceptions, it would require each exception to be publicly debated and affirmatively enacted. Unlike a piecemeal legislative approach, it would begin with the presumption that all discriminatory laws are invalid and place the burden of justification on those who wish to keep them. Furthermore, such a proposal would not sacrifice the virtues, symbolic and otherwise, of an amendment.

The details of such a proposal could vary. The power to exempt could be exercised before or after the Court acts; could extend to classes of laws (e.g., those promoting privacy) or to specific statutes only; could be effectuated by a majority or some higher vote of both houses of Congress; and might or might not require the approval of the President. The procedural roadblocks to exemption could be varied in difficulty to conform to congressional perceptions of the danger of wholesale exemptions which would gut the amendment's basic principle.

\section{Problems of Wording}

Assuming that the necessary majorities of both houses of Congress determine that neither the no-further-action route nor specific legislation is likely to be sufficiently responsive to the problem of sex discrimination, they will face the problem of drafting a satisfactory amendment. In the course of debate surrounding the amendments proposed in the 9Ist Congress, three general issues arose: the wording of the congressional enabling clause; the desirability of exempting certain classes of laws in the language of the amendment itself; and the exact wording of the governing principle.

As previously noted, ${ }^{122}$ recent judicial developments may portend severe limitations on Congress' power to reach sex discriminations in state law under section five of the fourteenth amendment. Assuming that Congress wants power to remedy sex discrimination analogous to its power under the fourteenth amendment to remedy racial discrimination, it is essential to include a properly worded enabling clause in any new amendment. As presently written, the enabling clause of the proposed equal rights amendment reads: "Congress and the several states shall have power, within their respective jurisdictions, to enforce this article by appropriate legislation." ${ }^{123}$

${ }^{123}$ S.J. Res. 6I, gIst Cong., Ist Sess. § I (1969) (emphasis added). 
A restrictive interpretation of the word "jurisdiction" might require the Court to find justification for Congressional legislation against the evils of sex discrimination in some other clause of the Constitution, like the commerce clause, rather than establish the new amendment as an independent source of power. Under this proposed version, Congress, through the commerce power, might not be able to legislate on sexual matters generally considered to be solely of state concern. ${ }^{124}$ While such a narrow interpretation may not be compelled, ${ }^{125}$ any uncertainty could be avoided by substituting the language of the fourteenth amendment's enabling clause, ${ }^{126}$ which has already undergone substantial judicial interpretation. Incorporation of the fourteenth amendment language in a new amendment would obviate Justice Black's contention in Mitchell that Congress has greater power to legislate in areas reserved to the states when the evil sought to be remedied is the evil which motivated the amendment's framers. Such an enabling clause would also avoid the difficulties inherent in Justice Stewart's suggestion in Mitchell that Congress can only legislate in areas judicially predetermined to violate equal protection. Obviously, sex would become such an area by the words of the amendment's governing principle. ${ }^{12 \pi}$

The second wording problem involves the desirability of including specific exceptions to the governing principle in the body of the amendment itself. Various exceptions have been proposed to exclude, for example, laws promoting privacy and the health or safety of women, and statutes involving service in the armed forces. ${ }^{128}$ There is little to be said for such proposals. In the first place, the governing principle of the amendment would spin briefly and disappear in the swirling whirlpool of broadly worded exceptions. Secondly, courts would face the diffcult threshold problem of determining the applicability of the exceptions, which would detract from analysis of the question of

\footnotetext{
${ }^{124}$ Hearings 208 (Letter of former Yale Law School Dean Louis Pollack); see p. I5I7 supra.

${ }^{125}$ See id. at 3 Io (testimony of Professor Emerson).

128 "The Congress shall have the power to enforce, by appropriate legislation, the provisions of this article." U.S. ConsT. amend. XIV, $\$ 5$.

${ }^{127}$ The equal rights amendment, as written, also grants power to the states to enforce it by appropriate legislation. This grant of power is unnecessary, as the states can already legislate, within their reserved powers, to eliminate sex discrimination. U.S. Const. amend. X.

${ }^{128}$ S.J. Res. 23I, 9rst Cong., Ist Sess. (1969), contains a proposed amendment which would

not impair ... the validity of any law ... which exempts women from compulsory military service or which is reasonably designed to promote the health, safety, privacy, education or economic welfare of women, or to enable them to perform their duties as homemakers or mothers.
} 
discrimination. Finally, statutes falling under the specific exceptions written into the Constitution would be immune to future judicial scrutiny in light of changing knowledge and attitudes. ${ }^{129}$

Finally, Congress must determine the wording of the governing principle itself. Two alternatives have emerged. The first says that "equality of rights" shall not be denied. ${ }^{130}$ The second is patterned after the last phrase of the first section of the fourteenth amendment: "Neither the United States nor any State shall on account of sex deny to any person within its jurisdiction the equal protection of the laws." ${ }^{131}$ Proponents of the equal rights language are divided as to whether "equality of rights" is equivalent to "equal protection" or is something different. ${ }^{132}$

The divisions among proponents and the vagueness of the concept of "equality of rights" have led to fears that courts would interpret the new amendment, not as a requirement for active review, but as a mandate to sweep away all statutory sex distinctions per se, with no exceptions. ${ }^{133}$ Such a per se rule would be undesirably rigid because it would leave no room to retain statutes which may properly reflect inherent differences between the sexes or statutes which promote personal bodily privacy. Even if the "equality of rights" language were adopted, however, the fear of a per se interpretation seems unfounded. The equal protection language of the fourteenth amendment might have been subject to a per se approach, but, despite judicial hints to the contrary, ${ }^{134}$ it has never authoritatively received such an

${ }^{129}$ In contrast, the amendment proposed at pp. I520-2x supra allows for adaptations to changing knowledge and norms by simple legislative enactments.

${ }^{130}$ See p. 4499 supra for exact wording of the equal rights amendment's governing principle.

${ }^{131}$ See Ir6 Cong. Rec. 18,075 (daily ed. Oct. 14, r970) (remarks of Senator Bayh) for the original draft of this proposal. It was later modified because of the fear that specifying only that equal protection could not be abridged on account of sex might be interpreted to exclude sex discrimination from the scope of the privileges and immunities and due process clauses. See Letter of Professor Kanowitz, supra note 92, at 7-8. Accordingly, Senator Bayh's modified amendment includes sex discrimination within all the prohibitory clauses of the present fourteenth amendment. See Senator Birch Bayh, News Release, No. ro4-7o (Nov. 2, I970).

${ }^{132}$ Compare Hearings I64-65 (testimony of Professor Kanowitz), and id. at 301 (testimony of Professor Emerson) (court could make proposed equal rights amendment a constitutional redundancy with more stringent interpretations of the equal protection clause), with Letter from Professor Pauli Murray, Brandeis University, to Senators Birch Bayh and Marlow W. Cook, Nov. 8, I970, on file at the Harvard Law Review (distinguishing the concepts of "equal rights" and "equal protection").

${ }^{133}$ See, e.g., Hearings 74 (testimony of Professor Freund).

${ }^{134}$ McLaughlin v. Florida, 379 U.S. I84, I98 (I964) (Stewart, J., concurring) (suggesting a per se approach limited to criminal cases). 
interpretation. ${ }^{135}$ Since the cultural stigma of slavery is greater than that of womanhood, and since the empirical differences between the sexes appear far greater than those between the races, ${ }^{136}$ it is difficult to imagine the Court extrapolating from the phrase "equality of rights" to require that every sex distinction fall.

While the chance of a per se interpretation of the "equality of rights" language being adopted is slight, the proponents of the equal protection alternative argue persuasively that the equal rights terminology introduces an unnecessary element of uncertainty into the situation, ${ }^{137}$ as the concept of equal rights has no history, and the concept of equal protection seems sufficient to the task. To a large extent, however, the debate may be much ado about nothing, since a constitutional amendment using either phrase will compel the Supreme Court to adopt a standard of active review in evaluating classifications based on sex.

${ }^{135}$ See Hamm v. Virginia State Bd. of Elections, $2 \hat{j}^{\circ}$ F. Supp. $\times 56$ (E.D. Va.), aff'd sub nom. Tancil v. Woolls, 379 U.S. Ig (I964) (divorce records can be kept indicating race of parties); Lee v. Washington, 390 U.S. 333,334 (Ig68) (Black, J., concurring) (prison authorities have right to take racial tensions into account in maintaining prison discipline, if they act in good faith).

${ }^{136}$ See pp. I508-09 supra.

${ }^{137}$ See Report 8o. 